\title{
Tafluprost once daily for treatment of elevated intraocular pressure in patients with open-angle glaucoma
}

This article was published in the following Dove Press journal:

Clinical Ophthalmology

20 December 2012

Number of times this article has been viewed

Yang Liu

Weiming Mao

Department of Cell Biology and Anatomy, North Texas Eye Research Institute, University of North Texas Health Science Center, Fort Worth, TX
Correspondence:Weiming Mao CBH449, 3500 Camp Bowie Blvd, Fort Worth, TX 76107, USA

Tel + I 8177350564

Fax + I 8177352637

Email weiming.mao@unthsc.edu
Abstract: Glaucoma is a leading cause of visual loss worldwide. Current antiglaucoma therapy focuses on lowering intraocular pressure to a safe level. In recent years, prostaglandin analogs have become the first-line agents for treating open angle glaucoma. Tafluprost, which was first reported in 2003, is a novel prostaglandin analog, and has been shown to be a potent ocular hypotensive agent in a number of preclinical and clinical studies. Also, its unique preservativefree formulation helps to decrease preservative-associated ocular disorders and improve patient compliance. In this review, studies from 2003 to 2012 focusing on the structure, metabolism, efficacy, and safety of tafluprost are summarized. These studies suggested that application of tafluprost once daily is a safe and effective treatment for patients with open angle glaucoma.

Keywords: tafluprost, prostaglandin analog, glaucoma, intraocular pressure, preservative-free formulation

\section{Prostaglandin $\mathbf{F}_{2 \alpha}$ analogs in open angle glaucoma}

Glaucoma is a leading cause of blindness worldwide. It is characterized by optic neuropathy and progressive concentric vision loss. Based on the status of the anterior chamber angle, glaucoma can be divided into open and closed angle glaucoma. Open angle glaucoma, especially primary open angle glaucoma, affects the majority of patients. Although primary open angle glaucoma and other open angle glaucomas have been studied for decades, the exact disease mechanisms are not clear. Numerous clinical studies have shown that elevated intraocular pressure is the primary risk factor and causative factor for the development and progression of open angle glaucoma. ${ }^{1-4}$ Lowering intraocular pressure has been found to be an effective method for preventing optic nerve damage and preserving vision. ${ }^{1-4}$

The current strategies for lowering intraocular pressure include decreasing aqueous humor production ( $\beta$-blockers and carbonic anhydrase inhibitors) and/or increasing outflow facility (prostaglandin analogs, cholinergic agents). Among these drugs, prostaglandin $\mathrm{F}_{2 \alpha}\left(\mathrm{PGF}_{2 \alpha}\right)$ analogs have become the first-line agents in treating open angle glaucoma because of their reliable intraocular pressure-lowering effect, good compliance (once daily application), and fewer side effects.

The $\mathrm{PGF}_{2 \alpha}$ analogs approved for clinical application include latanoprost, bimatoprost, travoprost, as well as the recently developed tafluprost. PGF $_{2 \alpha}$ analogs lower intraocular pressure by facilitating drainage of aqueous humor, predominantly through the uveoscleral outflow pathway, as well as to a lesser degree through the trabecular outflow pathway. ${ }^{5}$ It has been suggested that $\mathrm{PGF}_{2 \alpha}$ analogs bind to prostaglandin $\mathrm{F}$ receptors, activate signal transduction (probably via protein kinase $\mathrm{C}$ ), and upregu- 
late the expression of matrix metalloproteinases. All these biological changes lead to remodeling of the extracellular matrix, elevation in uveoscleral outflow facility, and controversial improvement in trabecular outflow facility. ${ }^{5}$

\section{Discovery of tafluprost and its metabolism}

Tafluprost (International Union of Pure and Applied Chemistry name isopropyl (5Z)-7- $\{(1 \mathrm{R}, 2 \mathrm{R}, 3 \mathrm{R}, 5 \mathrm{~S})-2-[(1 \mathrm{E})-3,3-\mathrm{di}-$ fluoro-4-phenoxybut-1-en-1-yl]-3,5-dihydroxycyclopentyl hept-5-enoate) was first reported in 2003. ${ }^{6}$ Nakajima et al screened several prostaglandin analogs and found tafluprost (AFP-168) to be a potent prostaglandin F receptor agonist, which demonstrated a significant intraocular pressurelowering effect in feline eyes. ${ }^{6}$

Tafluprost is a prodrug in an ester form, which ensures ideal tissue penetration. ${ }^{7}$ About $75 \%$ of topically administered tafluprost can be absorbed by the rat cornea. ${ }^{8}$ When tafluprost enters the cornea, it is hydrolyzed by corneal esterases to the active acid form and is soluble in the aqueous humor. ${ }^{7}$ Compared with other prostaglandin analogs, the major modification of tafluprost is the substitution of the C-15 hydroxyl group with two fluorine atoms. ${ }^{6}$ This modification renders tafluprost resistant to 15 -hydroxydehydrogenase. ${ }^{7}$ Therefore, tafluprost is only metabolized by beta-oxidation and subsequent oxidation. ${ }^{9,10}$ In the eye, topically applied tafluprost is converted to the active form, tafluprost acid, which has an affinity for the human prostaglandin F receptor that is 12 times higher than that of latanoprost. ${ }^{11}$

\section{Efficacy of tafluprost in animal studies}

\section{Intraocular pressure-lowering effects}

Nakajima et al first reported the intraocular pressure-lowering effects of tafluprost in naïve experimental cynomolgus monkeys. ${ }^{6}$ In that study one eye was treated with $20 \mu \mathrm{L}$ of $0.0005 \%$ tafluprost or $0.005 \%$ latanoprost, while the fellow eye was treated with vehicle control. The authors found that treatment with tafluprost resulted in a significant intraocular pressure reduction of up to about $2 \mathrm{mmHg} 4-8$ hours following treatment, which was equivalent to the effect of latanoprost. To study the effects of tafluprost in monkeys with elevated intraocular pressure, Takagi et al induced ocular hypertension in one eye of the cynomolgus monkeys with photocoagulation of the trabecular meshwork. ${ }^{12}$ The authors found that a single dose of topical tafluprost $0.0025 \%$ significantly lowered intraocular pressure in the hypertensive eyes by $11.8 \mathrm{mmHg}$ as well as in the normotensive fellow eyes by $3.1 \mathrm{mmHg}$. In contrast, $0.005 \%$ latanoprost reduced intraocular pressure by $9.5 \mathrm{mmHg}(P>0.05)$ and $2.1 \mathrm{mmHg}$, respectively. They also observed that application of tafluprost once daily was sufficient to maintain reduced intraocular pressure in monkey eyes due to the fact that tafluprost significantly reduced intraocular pressure at each trough time point (ie, at every 24 hours post application).

Like in primates, tafluprost is also effective in rodents. Akaishi et al treated male ddY inbred mice with $0.0015 \%$ tafluprost and measured their intraocular pressures using the invasive microneedle method. ${ }^{13}$ Tafluprost decreased intraocular pressure in the anesthetized mice by about $3 \mathrm{mmHg}$ 2-4 hours post treatment, and this intraocular pressure reduction could be further enhanced by prolonged tafluprost treatment or when used in combination with dorzolamide.

\section{Influence on retinal ganglion cell survival and ocular blood flow}

Some recent studies have suggested direct neuroprotective effects of tafluprost. However, little is known about these effects in human subjects because monitoring of retinal ganglion cell survival/death takes many years, and it is impossible to determine the protective effects benefiting from reduced intraocular pressure or "direct" neuroprotection. Therefore, most of the neuroprotective research data came from in vitro and ex vivo experiments.

Yamagishi et al compared the direct neuroprotective effects of latanoprost, travoprost, bimatoprost, bimatoprost acid, tafluprost, unoprostone, and PGF $2 \alpha \cdot{ }^{14}$ Primary rat retinal ganglion cell cultures were subjected to either $25 \mu \mathrm{M}$ glutamate for 72 hours or $5 \%$ oxygen (hypoxia) for 24 hours. Meanwhile, the cells were treated with one of the prostaglandin analogs. The authors reported that tafluprost, as well as latanoprost, bimatoprost, and bimatoprost acid, promoted retinal ganglion cell survival. Caution should be exercised when using retinal ganglion cell cultures to test prostaglandin analogs, because some studies used the transformed RGC5 cell line to test tafluprost. ${ }^{15}$ It is now clear that RGC5 is not of retinal ganglion cell origin. ${ }^{16}$ In addition to in vitro cell cultures, Bull et al studied the potential neuroprotective effects of tafluprost using retinal explant cultures (ex vivo) collected from rats with laser-induced optic nerve head damage or optic nerve crush. ${ }^{17}$ On the fourth day of explant culture, the authors found that tafluprost improved retinal ganglion cell survival, which was comparable to betaxolol. However, neither of these agents showed significant protection on day 7 . 
In addition to direct neuroprotection, some studies have suggested that tafluprost enhances ocular blood flow, which may indirectly contribute to neuroprotection. ${ }^{18-22}$ Akaishi et al from Santen Pharmaceutical Co, Ltd reported that tafluprost improved optic nerve head blood flow in rabbit eyes. ${ }^{20}$ The authors treated one of the rabbit eyes with topical prostaglandin analogs once daily, and compared optic nerve head blood flow with laser speckle flowgraphy before and after treatment. Tafluprost, latanoprost, and travoprost increased optic nerve head blood flow, and on day 14 and/ or 28 tafluprost was superior to the other two agents. Rabbit heart rates were not significantly altered by any of the prostaglandin analogs.

However, intraocular pressure reduction was not taken into account in the above study. Izumi et al measured retinal blood flow in cats treated with topical tafluprost or latanoprost using a laser Doppler velocimetry system. ${ }^{22}$ With similar intraocular pressure reduction, tafluprost did not show statistically significant improvement in retinal blood flow compared with latanoprost. Both prostaglandin analogs increased retinal blood flow compared with the control. In cynomolgus monkey eyes, Mayama et al found that topic tafluprost enhanced optic nerve head blood flow in naive eyes without a significant intraocular pressure reduction. ${ }^{19}$ In laser-induced glaucomatous monkey eyes, tafluprost improved optic nerve head blood flow as well as reduced intraocular pressure in laser-damaged eyes, but not the fellow eyes.

Some studies explored the mechanism(s) of tafluprostmediated ocular blood flow increase. Dong et al measured the contraction of isolated rabbit ciliary arteries under the influence of tafluprost. ${ }^{21}$ The authors found that tafluprost relaxed ciliary arteries that were precontracted with a high potassium solution, and proposed that inhibition of calcium entry from the extracellular space contributes at least partially to this relaxation. Kurashima et al precontracted isolated rabbit ciliary arteries with $10 \mathrm{nM}$ endothelin- 1 and treated them with several prostaglandin analogs. ${ }^{18}$ Tafluprost, latanoprost, and travoprost reversed vasoconstriction in about 30 minutes. The authors also experimentally induced ischemia in the optic nerve head by intravitreal injection of $5 \mathrm{pM}$ endothelin-1. This ischemic condition could be significantly improved by pretreatment with topical tafluprost and the other prostaglandin analogs 90,120 , or 240 minutes before endothelin-1 injection, suggesting that tafluprost is effective in antagonizing vasoconstriction mediated by endothelin-1.

\section{Intraocular pressure-lowing effects in human subjects Efficacy in patients with elevated intraocular pressure}

Several clinical studies have been conducted to assess the efficacy of tafluprost. Patients with primary open angle glaucoma or ocular hypertension were involved in a Phase III noninferiority study. ${ }^{11,23}$ In this study, the efficacy of $0.0015 \%$ tafluprost was compared with that of $0.005 \%$ latanoprost. After 4 weeks of administration of tafluprost or latanoprost, both treatments reduced intraocular pressure by similar levels, ie, $6.6 \pm 2.5 \mathrm{mmHg}(27.6 \% \pm 9.6 \%)$ and $6.2 \pm 2.5 \mathrm{mmHg}$ $(25.9 \% \pm 9.7 \%)$, respectively. In addition, $80.4 \%$ of the patients in the tafluprost group showed an intraocular pressure reduction of greater than $20 \%$ compared with a reduction of $70.6 \%$ in the latanoprost group. In another study, the efficacy of tafluprost after prolonged use was evaluated. Tafluprost demonstrated a stable intraocular pressure reduction of 4.9-5.7 mmHg throughout this 52-week study (http://www. santen.co.jp/medical/common/pdf/info_package/tanpu/ tapros.pdf). ${ }^{11}$

In Europe, research by Uusitalo et al further confirmed the noninferiority of tafluprost versus latanoprost, as well as the long-term efficacy and safety of tafluprost in patients with open angle glaucoma (including pigmentary and exfoliative glaucoma) and ocular hypertension. ${ }^{24}$ The authors found that after 24 months of treatment, the mean intraocular pressure reduction from baseline was $7.1 \mathrm{mmHg} / 29.1 \%$ in the tafluprost-treated group and $7.7 \mathrm{mmHg} / 32.2 \%$ in latanoprosttreated group. ${ }^{24}$ Other clinical studies also showed additional intraocular pressure-lowering effects ranging from -6.22 to $-6.79 \mathrm{mmHg}$ when tafluprost was combined with the $\beta$-blocker timolol ${ }^{25}$ (see Table 1 for summary).

\section{Efficacy in patients with normal tension glaucoma}

Tafluprost also lowers intraocular pressure in patients with normal tension glaucoma. A Phase III study was conducted in 94 Japanese patients to evaluate whether tafluprost is effective in normal tension glaucoma. ${ }^{26}$ The intraocular pressure reduction in patients treated with tafluprost was $4.0 \pm 1.7 \mathrm{mmHg}$, which was significantly greater than that in the placebo-treated group. Nakano et al conducted another clinical study in 44 patients with normal tension glaucoma and baseline intraocular pressure of no more than $16 \mathrm{mmHg} .{ }^{27}$ After 12 weeks of treatment with tafluprost once daily in 
Table I Summary of major clinical trials of tafluprost

\begin{tabular}{|c|c|c|c|c|c|}
\hline Country & Patients (n) & Prescription & Treatment & IOP reduction & Reference \\
\hline Japan & $\begin{array}{l}109 \text { patients with POAG } \\
\text { and OHT }\end{array}$ & Tafluprost $0.0015 \%$ & 4 weeks & $\begin{array}{l}6.6 \pm 2.5 \mathrm{mmHg} \\
(27.6 \pm 9.6 \%)\end{array}$ & 26 \\
\hline Japan & $\begin{array}{l}35 \mathrm{I} \text { patients with OAG } \\
\text { (including NTG) and OHT }\end{array}$ & Tafluprost $0.0015 \%$ & 52 weeks & $4.9-5.7 \mathrm{mmHg}$ & $\begin{array}{l}\text { See product overview: http:// } \\
\text { www.santen.co.jp/medical } \\
\text { /common/pdf/info_package/ } \\
\text { tanpu/tapros.pdf }\end{array}$ \\
\hline Japan & $\begin{array}{l}44 \text { patients with NTG } \\
(\mathrm{IOP} \leq 16 \mathrm{mmHg})\end{array}$ & Tafluprost $0.0015 \%$ & 12 weeks & $3.0 \pm 1.4 \mathrm{mmHg}$ & 27 \\
\hline Europe & $\begin{array}{l}533 \text { patients with OAG } \\
\text { and } \mathrm{OHT}\end{array}$ & Tafluprost $0.0015 \%$ & 24 months & $\begin{array}{l}7.1 \mathrm{mmHg} \\
(29.1 \%)\end{array}$ & 24 \\
\hline Italy & $\begin{array}{l}185 \text { patients with OAG or OHT, } \\
\text { uncontrolled by timolol monotherapy }\end{array}$ & Tafluprost $0.0015 \%$ & 12 weeks & $6.22-6.79 \mathrm{mmHg}$ & 25 \\
\hline $\begin{array}{l}\text { US, Spain, } \\
\text { Switzerland }\end{array}$ & 643 patients with OAG or OHT & $\begin{array}{l}\text { Preservative-free } \\
\text { tafluprost } 0.0015 \%\end{array}$ & 12 weeks & $6.6-7.2 \mathrm{mmHg}$ & 30 \\
\hline
\end{tabular}

Abbreviations: POAG, primary open angle glaucoma; OHT, ocular hypertension; NTG, normal tension glaucoma; OAG, open angle glaucoma; IOP, intraocular pressure.

one eye, the treated eyes had a mean intraocular pressure of $10.2 \pm 1.6 \mathrm{mmHg}$ ( $3 \mathrm{mmHg}$ intraocular pressure reduction) compared with $12.1 \pm 1.5 \mathrm{mmHg}$ in the untreated fellow eyes (see Table 1 for summary).

\section{Comparison of tafluprost with other intraocular pressure-lowering agents}

Schnober et al reported that $0.004 \%$ travoprost produced a slightly lower diurnal intraocular pressure $(-0.5 \mathrm{mmHg})$ than $0.0015 \%$ tafluprost in patients with primary open angle glaucoma or normal tension glaucoma. ${ }^{28}$ Ranno et al compared the ocular hypotensive effects of tafluprost (preservative-free formulation) with other prostaglandin analogs. ${ }^{29}$ The authors found that tafluprost had a comparable intraocular pressurelowering efficacy compared with travoprost or latanoprost at each time point following treatment. Although statistical analysis showed that bimatoprost lowered intraocular pressure significantly more than tafluprost (by $1 \mathrm{mmHg}$ ), this slight difference was not clinically significant.

Chabi et al compared the efficacy of $0.0015 \%$ preservativefree tafluprost to $0.5 \%$ timolol in a randomized, multicenter clinical trial..$^{30} \mathrm{~A}$ total of 643 patients with primary open angle glaucoma and ocular hypertension were enrolled in this 12-week study. Tafluprost and timolol showed comparable intraocular pressure-lowering efficacy (see Table 2 for summary).

\section{Efficacy of preservative-free formulation}

A preservative-free formulation has been introduced for prostaglandin analogs to reduce the preservative-related side effects and improve patient compliance. In a singlecenter Phase I study, Uusitalo et al evaluated the pharmacokinetics and safety profiles of preservative-free and preservative-containing tafluprost. ${ }^{31}$ The authors did not find statistically significant differences in pharmacokinetic parameters between these two formulations after either single or repeated (up to 8 days) application. The incidence of ocular hyperemia was similar in both formulations, but less severe with preservative-free tafluprost. In a multicenter Phase III study carried out by Hamacher et al, the efficacy and safety of tafluprost in the two formulations was further evaluated in 43 patients with primary open angle glaucoma or ocular hypertension after 4 weeks of treatment. ${ }^{32}$ The preservative-free formulation was generally well tolerated, and demonstrated intraocular pressure reduction equivalent to that of the preservative-containing formulation.

An improvement in tolerability of preservative-free tafluprost in patients who experienced ocular surface damage caused by other prostaglandin analogs was also reported. Uusitalo et al investigated 158 patients switched from preservative-containing latanoprost to preservative-free tafluprost due to ocular surface side effects. ${ }^{33}$ After 12 weeks of treatment with preservative-free tafluprost, the authors found that the intraocular pressure in the patients did not change significantly, but patient tolerability was improved. As a result, patient satisfaction and quality of life were also improved. In another study, 118 patients with poor intraocular pressure control and/or tolerability issues switched from preservative-containing prostaglandin analogs (latanoprost, travoprost, and bimatoprost) to preservative-free tafluprost. ${ }^{34}$ Twelve weeks after the switch, further intraocular pressure reduction in patients with poor intraocular pressure control as well as significant improvement in both objective clinical signs and subjective symptoms were observed. At the end of the study, the number of patients with moderate and severe hyperemia decreased by $41.3 \%$. The efficacy and tolerability 
Table 2 Comparisons between $0.005 \%$ tafluprost and other prostaglandin analogs

\begin{tabular}{|c|c|c|c|c|c|c|}
\hline \multirow{2}{*}{$\begin{array}{l}\text { PG analogs } \\
\text { versus tafluprost }\end{array}$} & \multirow[t]{2}{*}{ IOP reduction } & \multirow[t]{2}{*}{ Treatment } & \multicolumn{3}{|c|}{ Side effects } & \multirow[t]{2}{*}{ Reference } \\
\hline & & & $\begin{array}{l}\text { Symptom } \\
\text { scores }\end{array}$ & $\begin{array}{l}\text { Clinical } \\
\text { examinations }\end{array}$ & $\begin{array}{l}\text { Patient- } \\
\text { reported } \\
\text { tolerability }\end{array}$ & \\
\hline $\begin{array}{l}\text { Travoprost } 0.004 \% \\
\text { versus tafluprost }\end{array}$ & $\begin{array}{l}\text { More than tafluprost } \\
\text { by } 0.5 \mathrm{mmHg}\end{array}$ & 6 weeks & ND & $\begin{array}{l}\text { Less conjunctival } \\
\text { hyperemia than tafluprost }\end{array}$ & ND & 28 \\
\hline $\begin{array}{l}\text { Latanoprost } 0.005 \% \\
\text { versus tafluprost }\end{array}$ & $\begin{array}{l}\text { ND, noninferiority of } \\
\text { tafluprost to latanoprost }\end{array}$ & $\begin{array}{l}4 \text { weeks- } \\
24 \text { months }\end{array}$ & NE & ND & NE & $11,23,29$ \\
\hline $\begin{array}{l}\text { Travoprost } 0.004 \% \\
\text { versus tafluprost }\end{array}$ & ND & 3 months & $\mathrm{NE}$ & ND & $\mathrm{NE}$ & 29 \\
\hline $\begin{array}{l}\text { Bimatoprost } 0.03 \% \\
\text { versus tafluprost }\end{array}$ & $\begin{array}{l}\text { More than tafluprost } \\
\text { by } \mathrm{I} \mathrm{mmHg}\end{array}$ & 3 months & NE & $\begin{array}{l}\text { More conjunctival } \\
\text { hyperemia and punctuate } \\
\text { keratitis than tafluprost }\end{array}$ & NE & 29 \\
\hline
\end{tabular}

Abbreviations: ND, no difference; NE, not evaluated; IOP, intraocular pressure; PG, prostaglandin.

of preservative-free tafluprost were further confirmed by Hommer et al in an investigation of 544 patients. ${ }^{35} \mathrm{~A}$ further intraocular pressure reduction of $3.5 \mathrm{mmHg}$ or $4.1 \mathrm{mmHg}$ was achieved 4-6 weeks or 12 weeks after switching from other preservative-containing prostaglandin analogs to tafluprost, respectively. Both objective clinical signs and subjective symptoms associated with ocular surface disease were improved after changing the medication. Similar findings were also reported by Januleviciene et al, ie, that preservative-free tafluprost had less impact on tear osmolality, increased tear film break-up time, and reduced discomfort while maintaining effective intraocular pressure control. ${ }^{36}$

In addition to the beneficial effects for patients with ocular surface damage, several studies showed that preservativefree tafluprost is well tolerated with fewer side effects than other preservative-containing intraocular pressure-lowering agents. Erb et al evaluated "real-life" data on the efficacy and safety of preservative-free tafluprost from participating ophthalmologists. ${ }^{37}$ Data were collected from 2123 patients with glaucoma or ocular hypertension receiving preservative-free tafluprost with or without a previous history of using other intraocular pressure-lowering agents. ${ }^{37}$ The preservative-free tafluprost lowered intraocular pressure from $19.5 \pm 4.4 \mathrm{mmHg}$ at baseline to $16.4 \pm 2.9 \mathrm{mmHg}$ after $6-12$ weeks. Around $86 \%$ of patients demonstrated "good" to "very good" comfort with tafluprost. Thirty patients discontinued medical treatment due to local intolerance, efficacy issues, systemic side effects, or a preference to use a multidose treatment regimen. Similarly, Milla et al investigated 134 patients with glaucoma or ocular hypertension previously treated with or without another prostaglandin analogs. ${ }^{38}$ After 3 months of administration, preservative-free tafluprost showed significant intraocular pressure reduction, regardless of previous prostaglandin analog application. All patients experienced a statistically significant improvement in clinical signs and symptoms except on the Schirmer's test, which evaluates tear secretion by using dry filter paper. Uusitalo et al also found that preservative-free tafluprost did not help to improve the results of Schirmer's test in patients with abnormal tear production..$^{33}$ For other ocular symptoms or signs, such as irritation and itching, the number of patients who experienced these decreased by approximately $50 \% 6$ and 12 weeks after switching from latanoprost to preservative-free tafluprost. However, the number of patients with abnormal Schirmer's test results decreased by only $10 \%$ and $12 \%$ at 6 and 12 weeks, respectively. Recently, Rossi et al reported the hypotensive effect of the preservative-free formulation, and no patients in their clinical study developed ocular surface disease during this 6-month treatment. ${ }^{39}$

\section{Safety of tafluprost in nonclinical studies \\ Toxicity to cornea and conjunctiva}

Ayaki and Iwasawa compared the toxicity of tafluprost containing benzalkonium chloride (BAK, a preservative) with other commercially available BAK-containing prostaglandin analogs by using multiple corneoconjunctival cell lines. ${ }^{40}$ The authors found that tafluprost was less toxic than travoprost, latanoprost, or unoprostone. Liang et al found that application of preservative-free $0.0015 \%$ tafluprost at 5 -minute intervals on 15 occasions had no toxic effects on the rabbit corneoconjunctival surface. ${ }^{41}$ It did not induce conjunctival congestion, infiltration of CD45+, TNFR1+ cells, or other inflammatory cells, nor did terminal deoxynucleotidyl transferase (TdT)mediated dUTP nick end labeling (TUNEL) assays reveal any significant cytotoxicity. In a later study, the same group reported that tafluprost did not affect conjunctiva-associated 
lymphoid tissue, which plays a key role in ocular surface immunology, confirming the safety of tafluprost for topical application. ${ }^{42}$ Furthermore, the authors showed that BAK is actually the primary cause of the cytotoxicity of these prostaglandin analog eye drops, because their BAK-free counterparts had minimal impact on the corneoconjunctival surface. $^{42}$

As with the corneoconjunctival surface in animals, tafluprost seems to have few toxic effects on human ocular cells. Pellinen et al treated cultured human corneal and conjunctival cells with preservative-free tafluprost as well as latanoprost, travoprost and bimatoprost, each containing BAK for one hour. ${ }^{43}$ At a $10 \%$ concentration, preservativefree tafluprost outperformed the other prostaglandin analogs in cell viability except for bimatoprost, which was similar to tafluprost regarding the effect on corneal epithelial cells. However, at a $0.1 \%$ concentration, all the tested eye drops showed similar effects on corneal cells. ${ }^{43}$ Brasnu et al studied $1: 10$ diluted preservative-free tafluprost (at a concentration of $0.00015 \%$ ) using the human corneal cell line, IOBA-NHC, and measured cytotoxicity based on membrane integrity, apoptosis, oxidative stress, and cell morphology. ${ }^{44}$ Consistent with the previous report, tafluprost caused less damage to cell cultures after 30 minutes of exposure compared with latanoprost, travoprost, or bimatoprost containing 1:10 diluted BAK. ${ }^{44}$ Nakagawa et al found that $0.0015 \%$ tafluprost containing $0.001 \%$ BAK and travoprost containing sofZia caused less damage to stratified human cultivated corneal epithelial sheets compared with latanoprost (with or without enzoate or BAK) as shown by carboxyfluorescein permeability assays. ${ }^{45}$

However, in contrast with studies showing the superior safety of tafluprost, Kahook and Ammar reported that $0.0015 \%$ tafluprost containing BAK was toxic to transformed human corneal epithelial cells (a $10.014 \mathrm{pRSV-t}$ cell line), causing death of $97 \%$ of cells after 25 minutes of exposure. $^{46}$

\section{Effects on orbital adipose tissue}

A recently discovered side effect associated with the topical prostaglandin analogs is deepening of the upper eye lid sulcus. ${ }^{47}$ Inoue et al observed 250 patients with primary open angle glaucoma or ocular hypertension receiving different prostaglandin analogs for more than 3 months. ${ }^{48}$ Deepening of the upper eye lid sulcus was evaluated both objectively and subjectively using photographs and self-reported questionnaires, respectively. All five prostaglandin ana$\operatorname{logs}$ tested induced deepening of the sulcus, and with an incidence caused by tafluprost of $18 \%$ (photographs) and $10 \%$ (questionnaires), which was lower than that caused by latanoprost, travoprost, or bimatoprost.

The exact mechanism for the deepening of the upper eye lid sulcus is not clear. However, the fact that a reduction in orbital fat and exophthalmos often coexist with changes in the eye lid suggests that atrophy of the orbital adipose tissue is the main reason. ${ }^{49-51}$ Choi et al treated human orbital adipose precursor cell cultures with 1:100 diluted prostaglandin analogs in their commercial formulations. ${ }^{52}$ All prostaglandin analogs tested decreased the expression of adipogenic transcription factor proliferator-activated receptor $\gamma$ and CCAATenhancer-binding protein $\alpha$, blocked intracellular cytosolic lipid droplet accumulation, and downregulated lipoprotein lipase, an adipocyte marker. Consistent with the clinical report described previously, ${ }^{48}$ this in vitro study showed that bimatoprost led to the most reduction in adipogenesis, while tafluprost performed similarly to travoprost, and latanoprost had the least effect on adipose cells. ${ }^{52}$

\section{Safety of tafluprost in clinical studies}

Sutton et al reported that tafluprost was generally well tolerated at concentrations from $0.0001 \%$ to $0.005 \%$, with ocular hyperemia being the most common adverse effect. ${ }^{53,54}$ However, some studies have suggested that $0.0015 \%$ tafluprost is more likely to cause ocular hyperemia than $0.005 \%$ latanopros ${ }^{55}$ but less likely than $0.03 \%$ bimatoprost. ${ }^{56}$ Long-term use of prostaglandin analogs may lead to increased pigmentation of the iris and periocular skin due to increased melanogenesis. ${ }^{57}$ Although tafluprost did not stimulate melanogenesis in cell cultures, ${ }^{6,12}$ there was no difference between tafluprost and latanoprost in inducing iris pigmentation in clinical studies. ${ }^{24}$

Nonocular side effects associated with tafluprost have been reported as well. For example, Uusitalo et al observed 11 nonocular adverse events in 8 patients receiving tafluprost and 9 events in 7 patients receiving latanoprost. ${ }^{24}$ No clinically significant changes in blood pressure or heart rate over the 24-month study period or laboratory parameters up to 12 months were found in association with tafluprost. ${ }^{24}$

\section{Conclusion}

Tafluprost $0.0015 \%$ is a safe, effective intraocular pressurelowering agent. Its unique preservative-free formulation not only maintains high efficacy but also improves patient compliance and comfort during long-term treatment. Preservative-free tafluprost may be particularly beneficial for 
patients with side effects affecting the ocular surface caused by preservative-containing eye drops.

\section{Disclosure}

The authors have no financial interests or other conflicts of interest to disclose in this work.

\section{References}

1. The Advanced Glaucoma Intervention Study. The relationship between control of intraocular pressure and visual field deterioration. The AGIS Investigators. Am J Ophthalmol. 2000;130:429-440.

2. Heijl A, Leske MC, Bengtsson B, Hyman L, Hussein M. Reduction of intraocular pressure and glaucoma progression: results from the Early Manifest Glaucoma Trial. Arch Ophthalmol. 2002;120:1268-1279.

3. Kass MA, Heuer DK, Higginbotham EJ, et al. The Ocular Hypertension Treatment Study: a randomized trial determines that topical ocular hypotensive medication delays or prevents the onset of primary openangle glaucoma. Arch Ophthalmol. 2002;120:701-713.

4. Lichter PR. Impact of intraocular pressure reduction on glaucoma progression. JAMA. 2002;288:2607-2608

5. Toris CB, Gabelt BT, Kaufman PL. Update on the mechanism of action of topical prostaglandins for intraocular pressure reduction. Surv Ophthalmol. 2008;53 Suppl 1:S107-S120.

6. Nakajima T, Matsugi T, Goto W, et al. New fluoroprostaglandin F(2alpha) derivatives with prostanoid FP-receptor agonistic activity as potent ocular-hypotensive agents. Biol Pharm Bull. 2003;26:1691-1695.

7. Pantcheva MB, Seibold LK, Awadallah NS, Kahook MY. Tafluprost: a novel prostaglandin analog for treatment of glaucoma. Adv Ther. 2011; 28:707-715.

8. Fukano Y, Kawazu K. Disposition and metabolism of a novel prostanoid antiglaucoma medication, tafluprost, following ocular administration to rats. Drug Metab Dispos. 2009;37:1622-1634.

9. Lands WE. The biosynthesis and metabolism of prostaglandins. Annu Rev Physiol. 1979;41:633-652.

10. Fukano Y, Kawazu K, Akaishi T, Bezwada P, Pellinen P. Metabolism and ocular tissue distribution of an antiglaucoma prostanoid, tafluprost, after ocular instillation to monkeys. J Ocul Pharmacol Ther. 2011;27: 251-259.

11. Aihara M. Clinical appraisal of tafluprost in the reduction of elevated intraocular pressure (IOP) in open-angle glaucoma and ocular hypertension. Clin Ophthalmol. 2010;4:163-170.

12. Takagi Y, Nakajima T, Shimazaki A, et al. Pharmacological characteristics of AFP-168 (tafluprost), a new prostanoid FP receptor agonist, as an ocular hypotensive drug. Exp Eye Res. 2004;78:767-776.

13. Akaishi T, Odani-Kawabata N, Ishida N, Nakamura M. Ocular hypotensive effects of anti-glaucoma agents in mice. $J$ Ocul Pharmacol Ther. 2009;25:401-408.

14. Yamagishi R, Aihara M, Araie M. Neuroprotective effects of prostaglandin analogues on retinal ganglion cell death independent of intraocular pressure reduction. Exp Eye Res. 2011;93:265-270.

15. Kanamori A, Naka M, Fukuda M, Nakamura M, Negi A. Tafluprost protects rat retinal ganglion cells from apoptosis in vitro and in vivo. Graefes Arch Clin Exp Ophthalmol. 2009;247:1353-1360.

16. Van Bergen NJ, Wood JP, Chidlow G, et al. Recharacterization of the RGC-5 retinal ganglion cell line. Invest Ophthalmol Vis Sci. 2009;50:4267-4272.

17. Bull ND, Johnson TV, Welsapar G, DeKorver NW, Tomarev SI, Martin KR. Use of an adult rat retinal explant model for screening of potential retinal ganglion cell neuroprotective therapies. Invest Ophthalmol Vis Sci. 2011;52:3309-3320.

18. Kurashima H, Watabe H, Sato N, Abe S, Ishida N, Yoshitomi T. Effects of prostaglandin $\mathrm{F}$ (2alpha) analogues on endothelin-1-induced impairment of rabbit ocular blood flow: comparison among tafluprost, travoprost, and latanoprost. Exp Eye Res. 2010;91:853-859.
19. Mayama C, Ishii K, Saeki T, Ota T, Tomidokoro A, Araie M. Effects of topical phenylephrine and tafluprost on optic nerve head circulation in monkeys with unilateral experimental glaucoma. Invest Ophthalmol Vis Sci. 2010;51:4117-4124.

20. Akaishi T, Kurashima H, Odani-Kawabata N, Ishida N, Nakamura M. Effects of repeated administrations of tafluprost, latanoprost, and travoprost on optic nerve head blood flow in conscious normal rabbits. J Ocul Pharmacol Ther. 2010;26:181-186.

21. Dong Y, Watabe H, Su G, Ishikawa H, Sato N, Yoshitomi T. Relaxing effect and mechanism of tafluprost on isolated rabbit ciliary arteries. Exp Eye Res. 2008;87:251-256.

22. Izumi N, Nagaoka T, Sato E, et al. Short-term effects of topical tafluprost on retinal blood flow in cats. J Ocul Pharmacol Ther. 2008;24:521-526.

23. Kuwayama Y KS. Phase III confirmatory study of $0.0015 \%$ DE-085 (Tafluprost) ophthalmic solution as compared to $0.005 \%$ latanoprost ophthalmic solution in patients with open-angle glaucoma or ocular hypertension. Atarashii Ganka. 2008;25:7.

24. Uusitalo H, Pillunat LE, Ropo A. Efficacy and safety of tafluprost $0.0015 \%$ versus latanoprost $0.005 \%$ eye drops in open-angle glaucoma and ocular hypertension: 24-month results of a randomized, double-masked Phase III study. Acta Ophthalmol. 2010;88:12-19.

25. Egorov E, Ropo A. Adjunctive use of tafluprost with timolol provides additive effects for reduction of intraocular pressure in patients with glaucoma. Eur J Ophthalmol. 2009;19:214-222.

26. Kuwayama Y, Komemushi S. Intraocular pressure lowering effect of $0.0015 \%$ tafluprost as compared to placebo in patients with normal tension glaucoma: randomized, double-blind, multicenter, Phase III study. Nihon Ganka Gakkai Zasshi. 2010;114:436-443. Japanese.

27. Nakano T, Yoshikawa K, Kimura T, Suzumura H, Nanno M, Noro T. Efficacy and safety of tafluprost in normal-tension glaucoma with intraocular pressure of $16 \mathrm{mmHg}$ or less. Jpn J Ophthalmol. 2011;55:605-613.

28. Schnober D, Hofmann G, Maier H, Scherzer ML, Ogundele AB, Jasek MC. Diurnal IOP-lowering efficacy and safety of travoprost $0.004 \%$ compared with tafluprost $0.0015 \%$ in patients with primary open-angle glaucoma or ocular hypertension. Clin Ophthalmol. 2010;4: 1459-1463.

29. Ranno S, Sacchi M, Brancato C, Gilardi D, Lembo A, Nucci P. A prospective study evaluating IOP changes after switching from a therapy with prostaglandin eye drops containing preservatives to nonpreserved tafluprost in glaucoma patients. Scientific World Journal. 2012;2012:804730.

30. Chabi A, Varma R, Tsai JC, et al. Randomized clinical trial of the efficacy and safety of preservative-free tafluprost and timolol in patients with open-angle glaucoma or ocular hypertension. Am J Ophthalmol. 2012;153:1187-1196.

31. Uusitalo H, Kaarniranta K, Ropo A. Pharmacokinetics, efficacy and safety profiles of preserved and preservative-free tafluprost in healthy volunteers. Acta Ophthalmol Suppl (Oxf). 2008;242:7-13.

32. Hamacher T, Airaksinen J, Saarela V, Liinamaa MJ, Richter U, Ropo A. Efficacy and safety levels of preserved and preservative-free tafluprost are equivalent in patients with glaucoma or ocular hypertension: results from a pharmacodynamics analysis. Acta Ophthalmol Suppl (Oxf). 2008;242:14-19.

33. Uusitalo H, Chen E, Pfeiffer N, et al. Switching from a preserved to a preservative-free prostaglandin preparation in topical glaucoma medication. Acta Ophthalmol. 2010;88:329-336.

34. Hommer A, Kimmich F. Switching patients from preserved prostaglandin-analog monotherapy to preservative-free tafluprost. Clin Ophthalmol. 2011;5:623-631.

35. Hommer A, Mohammed Ramez O, Burchert M, Kimmich F. IOP-lowering efficacy and tolerability of preservative-free tafluprost $0.0015 \%$ among patients with ocular hypertension or glaucoma. Curr Med Res Opin. 2010;26:1905-1913.

36. Januleviciene I, Derkac I, Grybauskiene L, Paulauskaite R, Gromnickaite R, Kuzmiene L. Effects of preservative-free tafluprost on tear film osmolarity, tolerability, and intraocular pressure in previously treated patients with open-angle glaucoma. Clin Ophthalmol. 2012;6:103-109. 
37. Erb C, Lanzl I, Seidova SF, Kimmich F. Preservative-free tafluprost $0.0015 \%$ in the treatment of patients with glaucoma and ocular hypertension. Adv Ther. 2011;28:575-585.

38. Milla E, Stirbu O, Rey A, et al. Spanish multicenter tafluprost tolerability study. Br J Ophthalmol. 2012;96:826-831.

39. Rossi GC, Pasinetti GM, Raimondi M, et al. Efficacy and ocular surface tolerability of preservative-free tafluprost $0.0015 \%$ : a 6-month, single-blind, observational study on naive ocular hypertension or glaucoma patients. Expert Opin Drug Saf. 2012;11:519-525.

40. Ayaki M, Iwasawa A. Cytotoxicity of prostaglandin analog eye drops preserved with benzalkonium chloride in multiple corneoconjunctival cell lines. Clin Ophthalmol. 2010;4:919-924.

41. Liang H, Baudouin C, Pauly A, Brignole-Baudouin F. Conjunctival and corneal reactions in rabbits following short- and repeated exposure to preservative-free tafluprost, commercially available latanoprost and 0.02\% benzalkonium chloride. Br J Ophthalmol. 2008;92:1275-1282.

42. Liang H, Baudouin C, Labbe A, Riancho L, Brignole-Baudouin F. Conjunctiva-associated lymphoid tissue (CALT) reactions to antiglaucoma prostaglandins with or without BAK-preservative in rabbit acute toxicity study. PLoS One. 2012;7:e33913.

43. Pellinen P, Huhtala A, Tolonen A, Lokkila J, Maenpaa J, Uusitalo H. The cytotoxic effects of preserved and preservative-free prostaglandin analogs on human corneal and conjunctival epithelium in vitro and the distribution of benzalkonium chloride homologs in ocular surface tissues in vivo. Curr Eye Res. 2012;37:145-154.

44. Brasnu E, Brignole-Baudouin F, Riancho L, Guenoun JM, Warnet JM, Baudouin C. In vitro effects of preservative-free tafluprost and preserved latanoprost, travoprost, and bimatoprost in a conjunctival epithelial cell line. Curr Eye Res. 2008;33:303-312.

45. Nakagawa S, Usui T, Yokoo S, et al. Toxicity evaluation of antiglaucoma drugs using stratified human cultivated corneal epithelial sheets. Invest Opthalmol Vis Sci. 2012;53:5154-5160.

46. Kahook MY, Ammar DA. In vitro toxicity of topical ocular prostaglandin analogs and preservatives on corneal epithelial cells. J Ocul Pharmacol Ther. 2010;26:259-263.
47. Peplinski LS, Albiani Smith K. Deepening of lid sulcus from topical bimatoprost therapy. Optom Vis Sci. 2004;81:574-577.

48. Inoue K, Shiokawa M, Wakakura M, Tomita G. Deepening of the upper eyelid sulcus caused by 5 types of prostaglandin analogs. J Glaucoma. August 29, 2012. [Epub ahead of print.]

49. Jayaprakasam A, Ghazi-Nouri S. Periorbital fat atrophy - an unfamiliar side effect of prostaglandin analogues. Orbit. 2010;29:357-359.

50. Tappeiner C, Perren B, Iliev ME, Frueh BE, Goldblum D. Orbital fat atrophy in glaucoma patients treated with topical bimatoprost can bimatoprost cause enophthalmos? Klin Monbl Augenheilkd. 2008;225:443-445. German.

51. Filippopoulos T, Paula JS, Torun N, Hatton MP, Pasquale LR, Grosskreutz CL. Periorbital changes associated with topical bimatoprost. Ophthal Plast Reconstr Surg. 2008;24:302-307.

52. Choi HY, Lee JE, Lee JW, Park HJ, Jung JH. In vitro study of antiadipogenic profile of latanoprost, travoprost, bimatoprost, and tafluprost in human orbital preadiopocytes. J Ocul Pharmacol Ther. 2012;28: $146-152$.

53. Sutton A, Gilvarry A, Ropo A. A comparative, placebo-controlled study of prostanoid fluoroprostaglandin-receptor agonists tafluprost and latanoprost in healthy males. J Ocul Pharmacol Ther. 2007;23: 359-365.

54. Sutton A, Gouws P, Ropo A. Tafluprost, a new potent prostanoid receptor agonist: a dose-response study on pharmacodynamics and tolerability in healthy volunteers. Int J Clin Pharmacol Ther. 2008;46:400-406.

55. Mochizuki H, Itakura H, Yokoyama T, Takamatsu M, Kiuchi Y. Twenty-four-hour ocular hypotensive effects of $0.0015 \%$ tafluprost and $0.005 \%$ latanoprost in healthy subjects. Jpn J Ophthalmol. 2010;54: 286-290.

56. Aptel F, Denis P. Balancing efficacy and tolerability of prostaglandin analogues and prostaglandin-timolol fixed combinations in primary open-angle glaucoma. Curr Med Res Opin. 2011;27:1949-1958.

57. Cracknell KP, Grierson I, Hogg P, Appleton P, Pfeiffer N. Latanoprost-induced iris darkening: a morphometric study of human peripheral iridectomies. Exp Eye Res. 2003;77:721-730.
Clinical Ophthalmology

\section{Publish your work in this journal}

Clinical Ophthalmology is an international, peer-reviewed journal covering all subspecialties within ophthalmology. Key topics include: Optometry; Visual science; Pharmacology and drug therapy in eye diseases; Basic Sciences; Primary and Secondary eye care; Patient Safety and Quality of Care Improvements. This journal is indexed on Submit your manuscript here: http://www.dovepress.com/clinical-ophthalmology-journal

\section{Dovepress}

PubMed Central and CAS, and is the official journal of The Society of Clinical Ophthalmology (SCO). The manuscript management system is completely online and includes a very quick and fair peer-review system, which is all easy to use. Visit http://www.dovepress.com/ testimonials.php to read real quotes from published authors. 